\title{
Lipid Transport in the Human Newborn
}

\author{
PALMITATE AND GLYCEROL TURNOVER AND THE CONTRIBUTION OF \\ GLYCEROL TO NEONATAL HEPATIC GLUCOSE OUTPUT
}

\author{
P. F. Bougnéres, I. E. Karl, L. S. Hillman, and D. M. Bier, Departments of \\ Medicine and Pediatrics, Metabolism Division, Washington University School \\ of Medicine, St. Louis, Missouri 63110
}

\begin{abstract}
AB S T R A C T Free fatty acid (FFA) transport was measured in 11 and glycerol turnover in 5 newborns with continuous tracer infusion of $\left[1-{ }^{13} \mathrm{C}\right]$ palmitate or $\left[2-{ }^{13} \mathrm{C}\right]$ glycerol, respectively. In addition, simultaneous determination of glucose production in the latter group with $\left[6,6-{ }^{2} \mathrm{H}_{2}\right]$ glucose tracer and measurement of the appearance rate of $\left[{ }^{13} \mathrm{C}\right] \mathrm{glucose}$ derived from $\left[{ }^{13} \mathrm{C}\right]$ glycerol allowed calculation of gluconeogenesis from glycerol.
\end{abstract}

The average FFA inflow rate was $11.5 \pm 1.7 \mu \mathrm{mol}$ $\mathrm{kg}^{-1} \min ^{-1}, 2.5-4.5 \mathrm{~h}$ after the last feeding, and $16.7 \pm 2.8 \mu \mathrm{mol} \mathrm{kg} \mathrm{kmin}^{-1}, 5-12 \mathrm{~h}$ after the last meal. These rates are comparable to those found in adults only after 8-16 h and $\sim 72 \mathrm{~h}$ of fasting, respectively. FFA inflow in the newborn was directly correlated with time of fasting, plasma FFA level, and plasma glycerol level. Palmitate clearance and fractional removal were inversely related to palmitate level.

Glycerol flux averaged $4.4 \pm 0.5 \mu \mathrm{mol} \mathrm{kg}^{-1} \mathrm{~min}^{-1}$, a value three- to fourfold that of the postabsorptive adult. Approximately $75 \%$ of transported glycerol was converted to glucose and represented $5.0 \pm 0.6 \%$ of hepatic glucose production. Furthermore, there was a direct relationship between glycerol turnover and the fraction of glucose coming from glycerol.

Despite the absolutely elevated neonatal FFA and glycerol transport rates, these were quantitatively similar to values found in adults with comparable elevated substrate levels. Furthermore, other similarities with the adult in the relationships between inflow transport and substrate values, and between transport and fractional removal suggest that the regulatory aspects

Dr. Bougnères' present address is Pediatric Endocrinology, Hôpital St. Vincent De Paul, 75014 Paris, France.

Received for publication 27 November 1981 and in revised form 16 April 1982. of lipid transport in man are already well developed by the first day of life.

\section{INTRODUCTION}

The transition from intrauterine to extrauterine life is, of necessity, accompanied by major alterations in fuel homeostasis, largely the result of abrupt termination of the major fetal fuel, glucose. Although the human neonate is capable of producing glucose at a rate of $\sim 6 \mathrm{mg} \mathrm{kg}^{-1} \mathrm{~min}^{-1}$ (1), sufficient to meet cerebral energy needs, daily glucose production alone can barely satisfy the minimal metabolic rate of the term infant on the first day of life (2) and is far short of meeting the total energy requirements of the active, growing neonate $(2,3)$. Thus, because exogenous caloric intake is generally inadequate during early postnatal life, there is an absolute need for other oxidizable endogenous substrates to meet the infant's energy demands. As in the adult, mobilized fatty acids are the primary energy source. Immediately after birth, there is a dramatic rise in circulating free fatty acids (FFA) ${ }^{1}$ (4-7) and a simultaneous fall in respiratory quotient from above 0.8 to near 0.7 (8-10). In addition, compared with other species, the newborn has a dramatic accumulation of adipose tissue near the end of gestation (11), and has large fat stores approximating 10$15 \%$ of body weight at birth (11-13). In vitro, this adipose tissue is capable of releasing large amounts of FFA( 14). Furthermore, because lipolysis of adipose tissue triglyceride also releases glycerol into the circulation, accelerated lipid mobilization in the neonatal period might serve the important additional function

\footnotetext{
${ }^{1}$ Abbreviations used in this paper: FFA, free fatty acid; $R_{a}$, rate of appearance; $R_{c}$, clearance rate; $R_{d}$, rate of disappearance.
} 
of supplying substantial gluconeogenic substrate in the form of glycerol.

Nevertheless, there are no quantitative measurements of FFA and glycerol transport or of glycerol's contribution to hepatic glucose output in the human newborn. Largely, this deficiency has been due to the unavailability of ethically acceptable means for obtaining these data in neonates. Recently developed gas chromatography-mass spectrometry (GCMS) approaches using nonradioactive, carbon-13-labeled substrate tracers have allowed us to make these measurements in the human neonate.

\section{METHODS}

Patients. FFA turnover was measured in 11 infants (group A), and glycerol transport and gluconeogenesis from glycerol was determined in 5 newborns (group B) whose clinical characteristics are presented in Table $\mathrm{I}$. 10 were boys and 6 were girls. 10 were term infants, all of whom were appropriately-sized-for-gestational age. 6 were born prematurely and 2 of these infants (numbers 7 and 10) were small-for-gestational age. Because there were no discernable differences in the substrate and kinetic results related to gestational age, the subjects are subsequently discussed without reference to gestational age. Each of the subjects was born after an uncomplicated pregnancy, but infant number 8 had a low initial Apgar score responding to routine resuscitation, 9 mothers had premature rupture of membranes, and 1 mother of fraternal twins (numbers 14 and 15) had a temperature of $38^{\circ} \mathrm{C}$ during labor. Thus, 11 of the infants studied were receiving intravenous antibiotic therapy, but in none was infection confirmed with culture evidence.

At the time of study, all but one of the infants was asymptomatic and resting comfortably in an isolette. Infant number 9 had mild respiratory distress syndrome and was studied in an isolette with a $40 \%$ inspired $\mathrm{O}_{2}$ concentration. During the study period each infant was covered with a blanket to avoid hypothermia and rectal temperatures taken at the beginning and end of each study did not fall below $36.5^{\circ} \mathrm{C}$.

Medical care of each newborn studied was under control of the child's personal physician who designated the infant's feeding schedule. Thus, while there is a broad postprandial study range, no infant was specifically fasted for the purpose of the tracer experiment. Subjects 5 and 9 had received no oral feedings before study. These two infants, and the remaining 9 neonates treated with intravenous antibiotics, were receiving dextrose intravenously at a "keep open" rate of $<1 \mathrm{mg}$ dextrose $\mathrm{kg}^{-1} \mathrm{~min}^{-1}$ except for newborn number 9 whose dextrose infusion rate was $5.8 \mathrm{mg} \mathrm{kg}^{-1} \mathrm{~min}^{-1}$. In each instance, the intravenous solution was switched to $0.45 \%$ saline a miminum of $1.5 \mathrm{~h}$ (and generally $3 \mathrm{~h}$ ) before starting the tracer experiment.

Materials. $\left[1-{ }^{13} \mathrm{C}\right]$ palmitic acid $\left(90\right.$ atom $\left.\% 1-{ }^{13} \mathrm{C}\right),[5,5,-$ $\left.6,6-{ }^{2} \mathrm{H}_{4}\right]$ palmitic acid $\left(96\right.$ atom $\left.\%{ }^{2} \mathrm{H}_{4}\right),\left[2-{ }^{13} \mathrm{C}\right]$ glycerol $(94$

TABLE I

Clinical Characteristics of the Patients Studied

\begin{tabular}{|c|c|c|c|c|c|c|c|c|c|}
\hline Subject & Sex & $\begin{array}{c}\text { Gesta- } \\
\text { tional } \\
\text { age }\end{array}$ & Weight• & Weight & $\begin{array}{l}\text { Postnatal } \\
\text { age }^{\bullet}\end{array}$ & $\begin{array}{c}\text { Time }^{\bullet} \\
\text { since last } \\
\text { feeding }\end{array}$ & Intrapartum history & $\begin{array}{l}\text { Apgar } \\
\text { scores }\end{array}$ & $\begin{array}{c}\text { Condition at time } \\
\text { of study }\end{array}$ \\
\hline & & $w k$ & kg & percentile & $\boldsymbol{h}$ & $\boldsymbol{h}$ & & $\begin{array}{l}1 \mathrm{~min} / \\
5 \min \end{array}$ & \\
\hline
\end{tabular}

FFA study (group A)

$\begin{array}{rlll}1 & \text { M } & 42 & 4.20 \\ 2 & \text { M } & 40 & 2.91 \\ 3 & \text { M } & 40 & 3.53 \\ 4 & \text { M } & 38 & 2.60 \\ 5 & \text { M } & 39 & 2.93 \\ 6 & \text { M } & 37 & 2.67 \\ 7 & \text { F } & 36 & 2.00 \\ 8 & \text { M } & 34 & 2.20 \\ 9 & \text { F } & 35 & 2.03 \\ 10 & \text { M } & 34 & 1.56 \\ 11 & \text { M } & 40 & 3.27\end{array}$

$\begin{array}{rl}90 & 24 \\ 15 & 23 \\ 70 & 15 \\ 10 & 18 \\ 15 & 10 \\ 25 & 46 \\ 3 & 20 \\ 85 & 20 \\ 10 & 20 \\ 1 & 16 \\ 35 & 16\end{array}$

4
5
4.5
2
10
2.5
2
2
1.5
2
3.5

PRM $\ddagger$
PRM; C-Sect."
PRM
PRM
PRM
PRM
unremarkable
unremarkable
PRM
PRM
unremarkable

$8 / 9$
$7 / 9$
$9 / 9$
$8 / 9$
$9 / 10$
$6 / 8$
$8 / 9$
$4 / 7$
$2 / 8$
$6 / 8$
$8 / 9$

well
well
well
well
well
well
well
well
RDS, $\$ 40 \% \mathrm{O}_{2}$
well
well

Glycerol study (group B)

\begin{tabular}{llllllllll}
12 & M & 40 & 3.06 & 20 & 24 & 2.5 & unremarkable & $7 / 9$ & well \\
13 & F & 36 & 2.56 & 60 & 20 & 2 & PRM & $9 / 9$ & well \\
14 & F & 39 & 2.70 & 10 & 20 & 4 & maternal fever & $8 / 9$ & well \\
15 & F & 39 & 2.90 & 15 & 22 & 4 & maternal fever & $8 / 9$ & well \\
16 & F & 40 & 3.00 & 20 & 23 & 4 & unremarkable & $8 / 9$ & well \\
\hline
\end{tabular}

- At onset of tracer infusion study.

† PRM = premature rupture of membranes.

\&DS = respiratory distress syndrome.

" C-Sect = Caesarean section. 
atom \% $\left.2-{ }^{13} \mathrm{C}\right]$, and D-[6,6-2 $\left.\mathrm{H}_{2}\right]$ glucose $\left(97\right.$ atom $\left.\%{ }^{2} \mathrm{H}_{2}\right)$ were purchased from Merck, Sharp and Dohme Canada, LTD., Montreal, Quebec, Canada. Chemical and isotopic purity were confirmed by conventional gas chromatographic and mass spectrometric analyses. Each preparation was pyrogen free by standard rabbit body temperature measurements after intravenous administration according to federal guidelines in a licensed commercial laboratory. $\left[6,6-{ }^{2} \mathrm{H}_{2}\right] g$ lucose and $\left[2-{ }^{13} \mathrm{C}\right]$ glycerol were dissolved in $0.5 \mathrm{~N}$ saline and prepared for human use as described (1). $\left[1-{ }^{13} \mathrm{C}\right]$ palmitic acid was bound to fatty acid-free human albumin for intravenous administration as described (15).

Procedural methods. Infants were studied after obtaining written parental consent according to protocols approved by the Washington University Committee on Human Experimentation. In 11 of the infants, the peripheral intravenous "scalp vein" needle already in place for antibiotic administration was used for tracer infusion. In the remaining 5 infants a 25-gauge scalp vein needle was inserted into a peripheral vein, the infant was returned to the isolette, covered with a blanket, and allowed to rest and stabilize body temperature for at least $1 \mathrm{~h}$ before the onset of tracer infusion. At time zero of study, "base-line" samples were collected (see below) and the continuous infusion of labeled substrate was begun using a calibrated Harvard syringe pump (Har- vard Apparatus Co., Inc., S. Natick, MA) at the rate of $0.205 \pm 0.021(\mathrm{SE}) \mu \mathrm{mol} \mathrm{kg} \mathrm{gin}^{-1}\left[1-{ }^{13} \mathrm{C}\right] \mathrm{palmitic}$ acid (group A); $\quad 0.242 \pm 0.007 \mu \mathrm{mol} \mathrm{kg}^{-1} \mathrm{~min}^{-1}\left[6,6-{ }^{2} \mathrm{H}_{2}\right]$ glucose and $0.311 \pm 0.011 \mu \mathrm{mol} \mathrm{kg} \mathrm{kg}^{-1} \mathrm{~min}^{-1}\left[2-{ }^{13} \mathrm{C}\right]$ glycerol (group B) except for the first infant in the glycerol study (number 12) who received $\left[2-{ }^{13} \mathrm{C}\right] \mathrm{glycerol}$ at the rate of $0.429 \mu \mathrm{mol}$ $\mathrm{kg}^{-1} \mathrm{~min}^{-1}$. These rates were maintained for $120 \mathrm{~min}$ in the former and $135 \mathrm{~min}$ in the latter group.

Before the start of the tracer infusion and every $15 \mathrm{~min}$ from 60 to 120 or $135 \mathrm{~min}, 400 \mu \mathrm{l}$ arteriolized "heel stick" capillary blood samples were collected into iced centrifuge tubes, and the plasma was immediately separated by highspeed centrifugation. For the FFA study (group A) albuminbound $\left[{ }^{2} \mathrm{H}_{4}\right]$ palmitic acid internal standard (see below) was added to a $100-\mu$ l aliquot of the subject's plasma, which was then placed immediately into $5 \mathrm{ml}$ of Dole's mixture (isopropanol/heptane $\left./ \mathrm{H}_{2} \mathrm{SO}_{4}, 40: 10: 1\right)$, and the fatty acids were extracted by vigorous shaking. Plasma proteins were precipitated from an additional $50 \mu$ l of plasma by addition to an equal volume of cold $3 \mathrm{M}$ perchloric acid for subsequent substrate measurement (see below). In certain instances (Table II) inadequate sample size limited substrate measurement. For the glycerol study (group B), $50 \mu$ l of plasma was prepared for substrate determination as above. The remaining $100-150 \mu$ l of plasma was added to $0.5 \mathrm{ml}$ of $0.3 \mathrm{~N}$ bar-

TABLE II

Substrate Values ${ }^{\circ}$ during the Tracer Infusion Study

\begin{tabular}{|c|c|c|c|c|c|}
\hline Subject & $\begin{array}{l}\text { Plasma } \\
\text { glucose }\end{array}$ & $\begin{array}{c}\text { Plasma } \\
\text { palmitate }\end{array}$ & Plasma FFA & $\begin{array}{l}\text { Plasma } \\
\text { glycerol }\end{array}$ & $\begin{array}{c}\text { Plasma } \\
\beta \text {-hydroxybutyrate }\end{array}$ \\
\hline & $\mathrm{mg} / \mathrm{dl}$ & $\mu M$ & $\mu M$ & $\mu M$ & $\mu M$ \\
\hline \multicolumn{6}{|c|}{ FFA study (group A) } \\
\hline 1 & $54 \pm 1$ & $559 \pm 28$ & $1,339 \pm 41$ & $327 \pm 15$ & $167 \pm 6$ \\
\hline 2 & $49 \pm 5$ & $415 \pm 14$ & $1,026 \pm 13$ & $147 \pm 8$ & $89 \pm 6$ \\
\hline 3 & $63 \pm 3$ & $257 \pm 55$ & $851 \pm 160$ & $243 \pm 17$ & $116 \pm 9$ \\
\hline 4 & $91 \pm 5$ & $81 \pm 4$ & $230 \pm 8$ & 360 & $40 \pm 5$ \\
\hline 5 & $66 \pm 6$ & $462 \pm 15$ & $1,109 \pm 35$ & - & 281 \\
\hline 6 & $87 \pm 2$ & $185 \pm 6$ & $637 \pm 16$ & 148 & $74 \pm 2$ \\
\hline 7 & $42 \pm 1$ & $100 \pm 11$ & $272 \pm 29$ & $176 \pm 23$ & $34 \pm 3$ \\
\hline 8 & $58 \pm 2$ & $131 \pm 21$ & $422 \pm 70$ & 104 & $54 \pm 5$ \\
\hline 9 & $50 \pm 12$ & $522 \pm 50$ & $940 \pm 91$ & - & 259 \\
\hline 10 & $56 \pm 3$ & $125 \pm 12$ & $420 \pm 39$ & 155 & $38 \pm 1$ \\
\hline 11 & $80 \pm 2$ & $431 \pm 17$ & $956 \pm 48$ & $270 \pm 6$ & $155 \pm 7$ \\
\hline Mean & 63 & 297 & 746 & 214 & 119 \\
\hline SE & \pm 4.9 & 55 & 112 & 27 & 26 \\
\hline \multicolumn{6}{|c|}{ Glycerol study (group B) } \\
\hline 12 & $57 \pm 2$ & 99 & 289 & $68 \pm 3$ & $52 \pm 3$ \\
\hline 13 & $62 \pm 2$ & 81 & 230 & $46 \pm 2$ & $39 \pm 3$ \\
\hline 14 & $62 \pm 1$ & 173 & 665 & $68 \pm 3$ & $66 \pm 4$ \\
\hline 15 & $70 \pm 3$ & 302 & 1,165 & $74 \pm 2$ & $53 \pm 3$ \\
\hline 16 & $53 \pm 1$ & 263 & 1,039 & $137 \pm 1$ & $74 \pm 3$ \\
\hline Mean & 61 & 184 & 677 & 79 & 57 \\
\hline SE & 3 & 44 & 192 & 4 & 6 \\
\hline \multicolumn{6}{|c|}{ Grand mean } \\
\hline$\pm \mathrm{SE}$ & $62 \pm 3$ & $262 \pm 42$ & $724 \pm 94$ & $166 \pm 26$ & $99 \pm 19$ \\
\hline
\end{tabular}

- Average value $\pm \mathrm{SE}$ of samples taken during the final hour of study except for single values, which were taken at the end or at the beginning of the study. 
ium hydroxide, and the proteins were precipitated by subsequent addition of $0.5 \mathrm{ml}$ of $0.3 \mathrm{~N}$ zinc sulfate. After centrifugation, the supernatant was used for determination of isotopic enrichment in plasma glucose and glycerol as described below. In each of the glycerol studies, a single additional 200- $\mu$ l blood sample was obtained at the end of the study and prepared for plasma FFA analysis by extraction of the plasma into Dole's mixture as described earlier.

Analytical methods. Plasma glucose (16), glycerol (17), and $\beta$-hydroxybutyrate (18) were measured microfluometrically by specific enzymatic analyses. Plasma palmitate content and $\left[1-{ }^{13} \mathrm{C}\right]$ palmitate enrichment were measured by selected ion monitoring and isotope dilution GCMS as recently described (19). Briefly, FFA isolated from the Dole's mixture extract (20) were converted to methyl ester derivatives by treatment with $1 \% \mathrm{H}_{2} \mathrm{SO}_{4}$ in methanol. The resultant individual fatty acid methyl esters were resolved by gas chromatography (GC) as described $(15,19)$. Computer-controlled, electron impact, selected ion monitoring mass spectrometry (MS) (19) of the palmitic acid molecular ion cluster $(\mathrm{m} / \mathrm{z} 270,271$, and 274) representing unlabeled, tracer [1$\left.{ }^{13} \mathrm{C}\right]$, and internal standard $\left[5,5,6,6-{ }^{2} \mathrm{H}_{4}\right]$ palmitic acid, respectively, allowed subsequent calculation of plasma palmitate content and $\left[1-{ }^{13} \mathrm{C}\right]$ palmitate tracer enrichment (19). Plasma total FFA content was calculated from the summed individual fatty acid GC peak areas referenced to the palmitate content (15). Total plasma FFA calculated in this fashion is somewhat less than the value obtained by titration because the latter method also measures fatty acids of shorter chain length than those determined by GC analysis.

The $\mathrm{Ba}(\mathrm{OH})_{2}-\mathrm{ZnSO}_{4}$ plasma supernatant was subjected to sequential anion and cation exchange chromatography (21) and $100 \mu \mathrm{l}$ of the neutral eluate fraction was used to measure plasma $\left[6,6-{ }^{2} \mathrm{H}_{2}\right]$ glucose enrichment by selected ion monitoring GCMS as described (21). Plasma $\left[{ }^{13} \mathrm{C}\right]$ glucose (formed from $\left[2-{ }^{13} \mathrm{C}\right]$ glycerol) was measured in the same assay by measuring the $M+1$ ion as well. The latter was corrected for the natural isotopic contributions of the other glucose molecular species present in the ion cluster by standard mass spectrometric isotopic dilution equations equivalent in form to those previously presented for palmitate (19). The remainder of the ion exchange eluate was dried under $\mathrm{N}_{2}$ and the glycerol -1,2,3-triacetate ester prepared by addition of $20 \mu \mathrm{l}$ of acetic anhydride and $10 \mu \mathrm{l}$ of pyridine. The reaction was carried out at room temperature for $1 \mathrm{~h}$. Gas chromatographic resolution of glycerol triacetate was accomplished on a $2 \mathrm{~m} \times 2 \mathrm{~mm} 3 \%$ OV 17 column maintained at $115^{\circ} \mathrm{C}$, and $\left[2-^{13} \mathrm{C}\right]$ glycerol isotopic enrichment measured by electron impact, selected ion monitoring $\mathrm{MS}$ of the [M$\left.\mathrm{CH}_{2} \mathrm{OCOCH}_{3}\right]^{+}$ion $(\mathrm{m} / \mathrm{z}$ 145) reflecting unlabeled glycerol, and its corresponding $M+1$ ion $(\mathrm{m} / \mathrm{z} 146)$ representing carbon-13-labeled glycerol (after correction for natural ${ }^{13} \mathrm{C}$ background). In representative samples, methane chemical ionization and selected ion monitoring GCMS of the $\mathrm{MH}^{+}$ ion cluster (m/z 219 and 220$)$ produced results identical to those obtained by electron impact analysis.

Calculations. Plasma palmitate inflow transport (or rate of appearance, $R_{a}$ ), its rate of outflow (or disappearance, $R_{d}$ ), and its clearance rate $\left(R_{c}\right)$ were calculated from samples taken between 60 and 120 min of study as described (15). For this purpose, the volume of distribution of palmitate was equated with the plasma volume estimated from the data of Cassidy (22). The fractional removal rate of palmitate was calculated by dividing the outflow rate by the palmitate pool size (taken as plasma concentration $X$ plasma volume). In three of the group A newborns, plasma palmitate content and isotopic enrichment remained reasonably constant (SD/ mean $<0.10$ ) during the final 60 min of study and thus could be considered at or near steady state where $R_{a}=R_{d}=$ flux, a specialized case for the equations noted (15). Total FFA inflow and outflow transport rates were calculated from palmitate's fraction of total circulating FFA as described (15) because palmitate is a representative tracer for circulating fatty acids as a group (23).

In group $\mathrm{B}$, each subject achieved approximately constant $(\mathrm{SD} /$ mean $<0.11)$ values for plasma glucose and glycerol content, $\left[6,6-{ }^{2} \mathrm{H}_{2}\right]$ glucose enrichment, $\left[1-{ }^{13} \mathrm{C}\right]$ glucose enrichment, and $\left[2-{ }^{13} \mathrm{C}\right]$ glycerol enrichment during the latter $30-$ 45 min of study. Thus, glucose and glycerol flux $\left(R_{a}=R_{d}\right)$ were calculated by conventional steady-state tracer dilution equations (1). Using these values, the appearance rate of $\left[{ }^{13} \mathrm{C}\right]$ glucose and the rate of glycerol conversion to glucose were estimated by standard tracer precursor-product approaches (24).

\section{RESULTS}

Substrate levels. Plasma substrate levels in the studied infants are shown in Table II. None of the infants was hypoglycemic. Plasma palmitate averaged $262 \pm 42$ $\mu \mathrm{M}$. Because palmitate represented $36.2 \pm 2.1 \%$ of the circulating long chain FFA, a newborn value similar to that reported by others (25), total circulating FFA averaged $724 \pm 94 \mu \mathrm{M}$. This level is in the range previously reported for newborns on the first day of life $(5-7,26)$. The intersubject variability of plasma FFA was presumably due to the wide postprandial range of sampling in our infants whose plasma FFA levels were correlated directly with the time since their last feeding $(r=0.57, P=0.02) .8$ of 11 subjects in group A also showed broad intrasubject variability in plasma palmitate and FFA levels. In only four of these infants, however, were the variations systematic. In patient 3 , plasma palmitate declined from 388 to $134 \mu \mathrm{M}$ during the last hour of study. In patients 7, 8, and 9, plasma palmitate rose from 84 to $154 \mu \mathrm{M}$, from 89 to 209 $\mu \mathrm{M}$, and from 384 to $515 \mu \mathrm{M}$, respectively, during the last $60 \mathrm{~min}$ of study. These changes reflected the unequal plasma inflow and outflow rates (Table III). Likewise, there was wide intersubject variability in plasma glycerol and $\beta$-hydroxybutyrate levels, but these values were in the range reported for infants $(5,26)$, and both correlated significantly $(P<0.001)$ with the corresponding FFA concentrations (Fig. 1). The ratio of circulating glycerol to FFA averaged $0.25 \pm 0.04$, higher than the average value of $\sim 0.1$ found by Novak et al. (5), but within the range reported by Heim (27), Persson and Gentz (26), and Melichar and Wolf (28) for infants during the first days of life.

Palmitate and FFA transport. Table III presents the results of the $\left[1-{ }^{13} \mathrm{C}\right]$ palmitate tracer infusion study in group A. During the study, infused $\left[1-{ }^{13} \mathrm{C}\right]$ tracer reached an average isotope enrichment of 1.38 atom $\%$ excess. Palmitate (and consequently FFA) inflow 
TABLE III

FFA Kinetics in the Newborns Studied

\begin{tabular}{|c|c|c|c|c|c|}
\hline Subject & $\begin{array}{l}\text { Plasma }\left[1-{ }^{-18} \mathrm{C}\right] \\
\text { palmitate }\end{array}$ & Palmitate $\mathbf{R}_{\mathbf{a}}$ & Palmitate $\mathbf{R}_{\mathbf{d}}$ & $\begin{array}{l}\text { FFA } \\
\text { R. }\end{array}$ & $\begin{array}{c}\text { FFA } \\
\mathbf{R}_{d}\end{array}$ \\
\hline & $\begin{array}{l}\text { atom \% } \\
\text { excess }\end{array}$ & \multicolumn{2}{|c|}{$\mu \mathrm{mol} \mathrm{kg}^{-1} \min ^{-1}$} & \multicolumn{2}{|c|}{$\mu \mathrm{mol} \mathrm{kg}^{-1} \min ^{-1}$} \\
\hline 1 & $0.79 \pm 0.09$ & $5.3 \pm 0.2$ & $5.2 \pm 0.2$ & 12.7 & 12.5 \\
\hline 2 & $1.73 \pm 0.16$ & $5.4 \pm 0.3$ & $5.4 \pm 0.3$ & 13.4 & 13.4 \\
\hline 3 & $0.86 \pm 0.09$ & $7.7 \pm 0.8$ & $7.9 \pm 0.7$ & 25.5 & 26.2 \\
\hline 4 & $2.16 \pm 0.10$ & $2.6 \pm 0.1$ & $2.6 \pm 0.1$ & 7.4 & 7.4 \\
\hline 5 & $0.81 \pm 0.03$ & $8.7 \pm 0.3$ & $8.7 \pm 0.4$ & 20.9 & 20.9 \\
\hline 6 & $1.61 \pm 0.07$ & $3.9 \pm 0.06$ & $3.9 \pm 0.06$ & 13.4 & 13.4 \\
\hline 7 & $1.91 \pm 0.03$ & $2.8 \pm 0.03$ & $2.7 \pm 0.03$ & 7.6 & 7.3 \\
\hline 8 & $1.37 \pm 0.21$ & $3.2 \pm 0.5$ & $3.1 \pm 0.4$ & 10.3 & 9.9 \\
\hline 9 & $0.78 \pm 0.12$ & $10.1 \pm 0.4$ & $9.7 \pm 0.01$ & 18.2 & 17.5 \\
\hline 10 & $1.83 \pm 0.08$ & $3.6 \pm 0.1$ & $3.5 \pm 0.1$ & 12.1 & 11.9 \\
\hline 11 & $1.33 \pm 0.09$ & $5.0 \pm 0.2$ & $4.9 \pm 0.2$ & 11.1 & 11.0 \\
\hline Mean & 1.38 & 5.30 & 5.25 & 13.9 & 13.8 \\
\hline SE & 0.15 & 0.75 & 0.75 & 1.7 & 1.7 \\
\hline
\end{tabular}
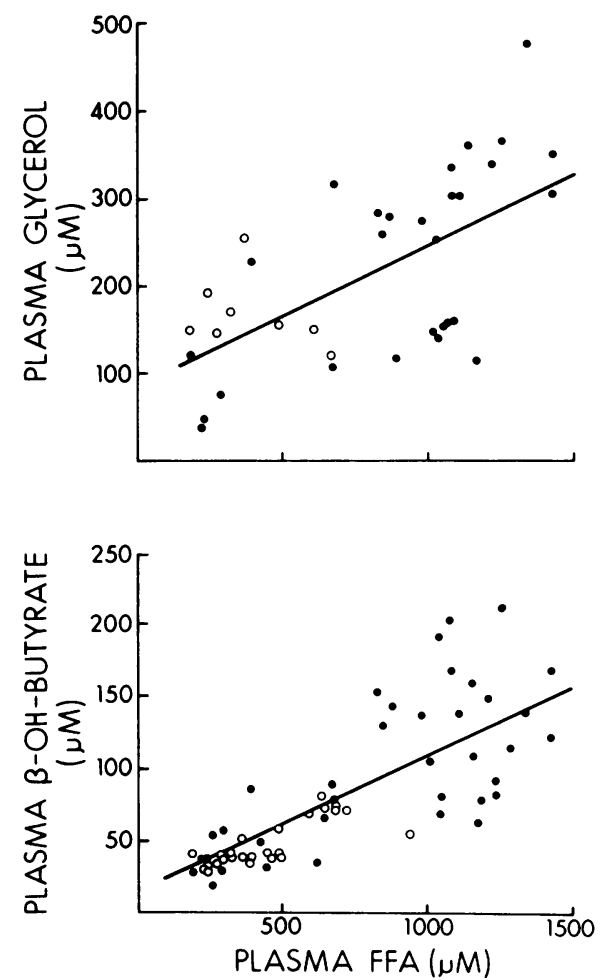

FIGURE 1 Relationships of plasma glycerol (upper panel) and $\beta$-hydroxybutyrate (lower panel) to plasma FFA. The closed circles are individual values from term infants and the open circles are from preterm infants. The regression line in the upper panel is defined by the equation $Y$ $=0.16 \mathrm{X}+84.7(r=0.62, P<0.001)$ and the line in the lower panel by the function $\mathrm{Y}=0.096 \mathrm{X}+13.67 \quad(r=0.78, P$ $<0.001$ ). and outflow transport rates were identical or nearly so in almost all subjects. Note, however, that palmitate inflow-outflow discrepancy of only $0.2-0.3 \mu \mathrm{mol}$ $\mathrm{kg}-{ }^{1} \mathrm{~min}^{-1}$ can lead to a substantial plasma palmitate change if maintained over a 60 -min period as noted above, particularly for subject 3 . As in the adult (15, 29-36), there was a close relationship $(r=0.84, P$ $<0.001$ ) between plasma palmitate level and palmitate inflow rate (Fig. 2). Similarly, palmitate inflow

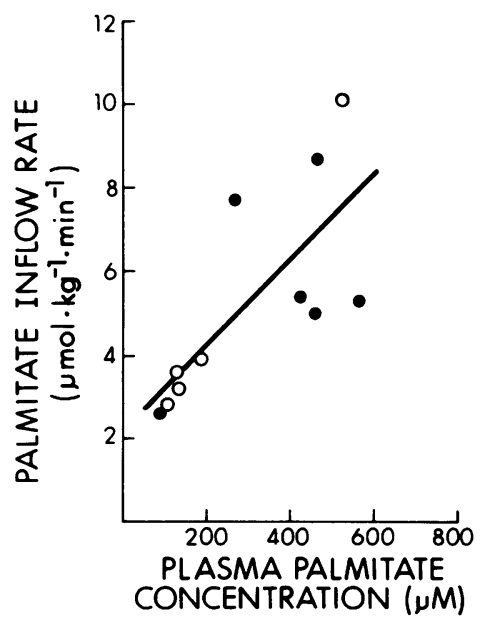

Figure 2 Relationship between average plasma palmitate level and palmitate inflow transport during the last $60 \mathrm{~min}$ of $\left[1-{ }^{13} \mathrm{C}\right]$ palmitate tracer infusion in group $\mathrm{A}$ subjects. The closed circles are values from term and the open circles values from preterm infants. The regressive equation is $\mathrm{Y}$ $=0.010 \mathrm{X}+2.4(r=0.73, P<0.01)$. 
correlated directly $(r=0.85, P<0.001)$ with plasma glycerol level as expected from the consequences of lipolysis of stored or dietary triglycerides.

The average FFA inflow rate was $13.9 \pm 1.7 \mu \mathrm{mol}$ $\mathrm{kg}^{-1} \mathrm{~min}^{-1}$. For the purposes of comparison, the infants were divided arbitrarily into two groups on the basis of feeding history. In six subjects (Nos. 4 and 6-10) FFA transport was calculated during a period $<4-4.5$ $h$ after the last feeding, a common intermeal interval for the human newborn. FFA inflow in these subjects averaged $11.5 \pm 1.7 \mu \mathrm{mol} \mathrm{kg-1} \mathrm{min}^{-1}$, a value comparable to that found in postabsorptive adults 8-12 h after their last meal $(15,33,37-39)$. In the five remaining infants who were not fed for $>5 \mathrm{~h}$ before FFA transport was calculated, FFA inflow averaged 16.7 \pm 2.8 $\mu \mathrm{mol} \mathrm{kg}^{-1} \mathrm{~min}^{-1}$, a value not reached in adults until they are fasted for $3 \mathrm{~d}$ or more $(38,39)$.

Plasma palmitate clearance ranged from 9 to $33 \mathrm{ml} /$ $\min$ (average $19.6 \pm 2.4 \mathrm{ml} / \mathrm{min}$ ) and was negatively correlated $(P<0.002)$ with plasma palmitate concentration in the range of 80 to $560 \mu \mathrm{M}$. Likewise (because clearance and fractional removal are related through a constant) fractional removal was also highly inversely correlated with plasma palmitate concentration (Fig. 3 ) as in the adult (37). The fractional rate constant declined from 0.6 to $0.2 / \mathrm{min}$ over a plasma palmitate range of 80 to $560 \mu \mathrm{M}$ (equivalent to an FFA range of $\sim 250$ to $1,500 \mu \mathrm{M}$ ), values remarkably similar to adult palmitate and FFA fractional removal at comparable FFA levels $(30,37,40,41)$. Hagenfeldt (30) was concerned that this inverse correlation might actually reflect an effect of the interindividual relationship between FFA and body weight. However, in subject 3 , who had the widest range of plasma palmitate during the course of the study, fractional removal was

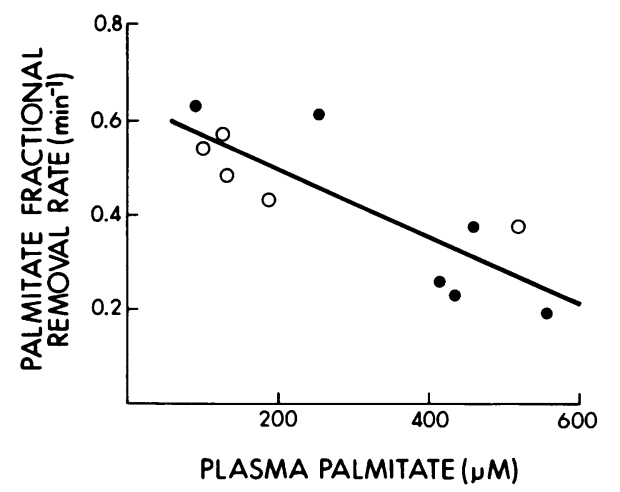

FIgURE 3 Relationship between average plasma palmitate content and fractional removal rate during the last $60 \mathrm{~min}$ of $\left[1-{ }^{13} \mathrm{C}\right]$ palmitate tracer infusion. The closed circles are term and the open circles preterm infants. The regression is defined by the equation $\mathrm{Y}=-7.13 \times 10^{-4} \mathrm{X}+0.64(r$ $=-0.83, P<0.001$ ). highly inversely correlated with palmitate level ( $r$ $=0.99$ ).

Glycerol metabolism. Glycerol flux in the group B infants averaged $4.4 \pm 0.5 \mu \mathrm{mol} \mathrm{kg}^{-1} \mathrm{~min}^{-1}$, a value three- to fourfold that of postabsorptive adults $(32,38$, 42) despite the fact that the infants were fasted only 4-6 h. Of the circulating glycerol, $3.3 \pm 0.6 \mu \mathrm{mol}$ $\mathrm{kg}^{-1} \mathrm{~min}^{-1}$, or $\sim 75 \%$ of the transported substrate, was converted to glucose. Because simultaneous glucose flux averaged $32.2 \pm 3.4 \mu \mathrm{mol} \mathrm{kg}^{-1} \mathrm{~min}^{-1}(5.8 \pm 0.6 \mathrm{mg}$ $\mathrm{kg}^{-1} \mathrm{~min}^{-1}$ ), a normal newborn value (1), glycerol contributed $5.0 \pm 0.6 \%$ of hepatic glucose production under the conditions of this study. If all the circulating glycerol had been converted to glucose it would have been responsible for $\sim 7 \%$ of glucose output. Despite the small number of subjects and the relatively narrow range of glycerol and glucose turnover rates, there was a significant $(r=0.85, P=0.03)$ direct relationship between glycerol transport and the fraction of glucose production coming from glycerol (Fig. 4). Bortz et al. (42) described a sigmoidal relationship between these two variables in the adult. Their curve, however, was "drawn by eye" and a linear fit appears equally plausible for their displayed data.

From the group B infants' FFA values (Table II) and the regression equation previously defined for the infants of group A (Fig. 2), the estimated FFA inflow for the group B infants was $12.8 \pm 1.9 \mu \mathrm{mol} \mathrm{kg}^{-1} \mathrm{~min}^{-1}$, in good agreement with the value of $11.5 \pm 1.7 \mu \mathrm{mol}$ $\mathrm{kg}^{-1} \mathrm{~min}^{-1}$ found in group A infants fasted for a similar period of time. Furthermore, the ratio of FFA transport to glycerol transport averaged $2.88 \pm 0.17$, close to the theoretical value of 3.0 expected if none of the hydrolyzed triglyceride fatty acid was reesterified in adipose tissue without release into the circulation.

\section{DISCUSSION}

Despite the obvious importance of lipid fuel for maintenance of energy balance in the newborn, we know of no direct measurements of FFA or glycerol transport in this age group. Our study demonstrates that FFA mobilization from triglyceride stores is a very active process during the first day of life even for moderately preterm infants. The observed neonatal FFA inflow transport rates of 7.4-13.4 $\mu \mathrm{mol} \mathrm{kg}^{-1} \mathrm{~min}^{-1}$ in 8 of the 11 infants agree remarkably well with the FFA turnover of 4.9-13.4 $\mu \mathrm{mol} \mathrm{kg}^{-1} \mathrm{~min}^{-1}$ found in four control children and four children recovered from Kwashiorkor, aged 8 mo-3 yr 8 mo, studied with [1$\left.{ }^{14} \mathrm{C}\right]$ palmitic acid (43), the only other pediatric FFA flux data of which we are aware. Three of our infants exceeded these values. Direct comparison with the adult is difficult because data in the latter group are generally obtained in the postabsorptive state after an 


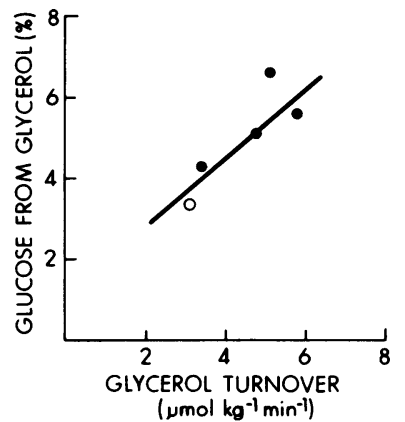

Figure 4 Relationship between glycerol transport and the fraction of glucose production coming from glycerol. Closed circles are term infants and the open circle is a preterm infant. The equation for the line is $\mathrm{Y}=0.93 \mathrm{X}+0.86(r=0.85$, $P=0.03)$.

8-12-h fast. However, our neonatal FFA turnover rates were also greater than those found in the adult by Nestel et al. (41) 6-8 h after discontinuation of sustained glucose consumption. Furthermore, it is of interest that newborns fasted for only $4 \mathrm{~h}$ or so have FFA flux rates comparable to those found in postabsorptive adults, while infants fasted for 5-12 h have FFA inflow transport rates achieved by the adult only after several days of fasting.

Because the newborn is generally fed on an approximately-every-4-h basis, one might estimate the total daily fatty acid transport from the group $\mathrm{A}$ infants who were studied within $5 \mathrm{~h}$ of their last feeding. From the observed average FFA inflow transport rate of $11.5 \pm 1.7 \mu \mathrm{mol} \mathrm{kg}^{-1} \mathrm{~min}^{-1}$, total daily FFA transport is on the order of $4-5 \mathrm{~g} \mathrm{~kg}^{-1} \mathrm{~d}^{-1}$. In the adult, $\sim 30 \%$ of FFA turnover is oxidized $(36,39)$. If one assumes the same fractional oxidation rate for the newborn (because such data are not yet available) the neonate would oxidize $1.2-1.5 \mathrm{~g}$ of fat per kilogram body weight daily, equivalent to $11-13.5 \mathrm{kcal} \mathrm{kg}^{-1} \mathrm{~d}^{-1}$. The latter values represent one-fourth to one-third of the minimal energy requirements of the newborn on the first days of life (2). This range agrees well with respiratory quotient estimates of lipid contribution to daily energy expenditures in newborns receiving oral or intravenous nutrients but reflects only one-half to one-third of the lipid's contribution to total energy metabolism in unfed neonates $(27,44-47)$.

As in the adult (29-37), fatty acid levels in our newborns were directly correlated with inflow transport (Fig. 2) and inversely correlated with fractional removal (Fig. 4). Furthermore, there was general similarity between neonatal and adult fractional removal rates at different FFA levels, as well as close agreement between the regression equation for FFA content and inflow transport in our patients and the average regression calculated from data presented in eight adult studies (15, 29-35) (Fig. 5). Although it was not possible to accurately calculate the variance about the latter adult regression line because all of the individual values are not known, it seems clear from the data points for our newborn regression equation (Fig. 2) that the two lines in Fig. 5 are unlikely to be statistically different. Taken together, the similar adult and newborn relationships between FFA concentrations and kinetic parameters suggest that the regulatory systems controlling these relationships are already fully established in man on the first day of life.

As expected from the above FFA data and from the calculated FFA/glycerol ratio near 3.0, neonatal glycerol transport related to available adult glycerol turnover information in much the same fashion as did the FFA data. Thus, despite a relatively short fast, neonatal glycerol turnover was severalfold that of the postabsorptive adult $(32,38,42)$. Nevertheless, because the average neonatal glycerol flux of $4.4 \mu \mathrm{mol} \mathrm{kg}^{-1} \mathrm{~min}^{-1}$ represents transport of only $\sim 0.6 \mathrm{~g} \mathrm{~kg}^{-1} \mathrm{~d}^{-1}$, glycerol is unlikely to be a major fuel source under usual circumstances.

Glycerol's other role of gluconeogenic precursor, however, requires discussion. In this study, $75 \%$ of the transported glycerol was converted to glucose. That the bulk of glycerol turnover becomes new glucose is consistent with the value of $40-80 \%$ glycerol carbon converted to glucose carbon in the lean adult (42), $50 \%$ in newborn pups (48), and $\sim 70 \%$ in the rat (49). In our infants, the $3.3 \pm 0.6 \mu \mathrm{mol} \mathrm{kg}^{-1} \mathrm{~min}^{-1}$ of glycerol that became glucose represented $5 \%$ of glucose output, a contribution similar to the range of $1.9-5.2 \%$ found in postabsorptive adults (42). Thus, glycerol's gluconeogenic contribution is about half that of alanine's in infants $<8 \mathrm{~h}$ of age (50). Hall et al. (51) also found

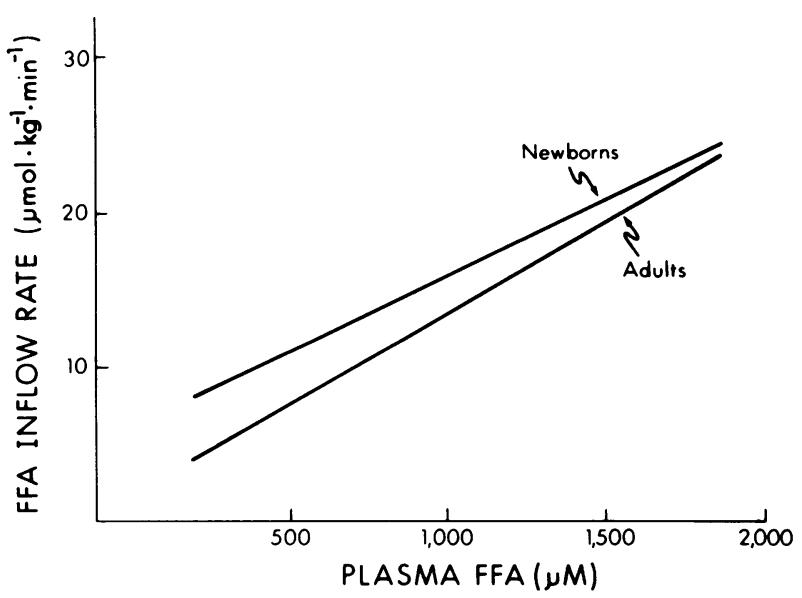

Figure 5 Relationships between plasma FFA content and FFA inflow transport in the newborn (this study) and in the adult (mean of values calculated from individual regression equations given in references $15,29-35$ ). The newborn line is defined by the equation $\mathrm{Y}=0.010 \mathrm{X}+6.0$ and the adult average function is $\mathrm{Y}=0.012 \mathrm{X}+1.0$. 
TABLE IV

Glucose and Glycerol Kinetics and the Conversion of Glycerol to Glucose in the Newborns Studied

\begin{tabular}{|c|c|c|c|c|c|c|c|c|c|}
\hline Subject & $\begin{array}{l}{\left[1 \cdot{ }^{13} \mathrm{C}\right]} \\
\text { Glycerol }\end{array}$ & $\begin{array}{c}{\left[6,6-^{2} \mathrm{H}_{2}\right]} \\
\text { Glucose }\end{array}$ & {$\left[{ }^{18} \mathrm{C}\right]$ Glucose } & $\begin{array}{l}\text { Glycerol } \\
\text { flux }\end{array}$ & $\begin{array}{c}\text { Glucose } \\
\text { flux }\end{array}$ & $\begin{array}{l}\text { Glycerol } \\
\text { to glucose } \\
\text { conversion }\end{array}$ & $\begin{array}{c}\text { Fraction of } \\
\text { glycerol } \\
\text { converted } \\
\text { to glucose }\end{array}$ & $\begin{array}{c}\text { Fraction of } \\
\text { glucose coming } \\
\text { from glycerol }\end{array}$ & $\begin{array}{l}\text { Maximal } \\
\text { contribution of } \\
\text { glycerol to } \\
\text { glucosel }\end{array}$ \\
\hline & \multicolumn{6}{|c|}{ 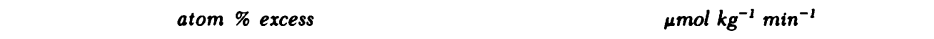 } & $\%$ & $\%$ & $\%$ \\
\hline 12 & $11^{\circ} \pm 0.4$ & $0.69 \pm 0.02$ & $0.90 \pm 0.01$ & 3.4 & 35.6 & 3.1 & 91 & 4.3 & 4.8 \\
\hline 13 & $7.7 \pm 0.1$ & $0.92 \pm 0.06$ & $0.52 \pm 0.02$ & 3.1 & 22.8 & 1.5 & 48 & 3.3 & 6.8 \\
\hline 16 & $5.9 \pm 0.1$ & $0.95 \pm 0.03$ & $0.60 \pm 0.01$ & 4.8 & 28.4 & 2.9 & 60 & 5.1 & 8.4 \\
\hline Mean & 7.1 & 0.76 & 0.69 & 4.4 & 32.2 & 3.3 & 72.8 & 5.0 & 7.0 \\
\hline SE & 1.1 & 0.08 & 0.07 & 0.5 & 3.2 & 0.6 & 8.1 & 0.6 & 0.6 \\
\hline
\end{tabular}

- Infant 12 was infused with a significantly higher dose of $\left[2-{ }^{13} \mathrm{Clglycerol}\right.$ (see text).

$\ddagger$ If all glycerol turnover were converted to glucose.

that glycerol's contribution to glucose production was about half that of alanine in newborn dogs. But, in their study, both glycerol and alanine each supplied approximately twice the fraction of glucose carbon than the respective values found in the human infant.

In the human, FFA values rarely exceed $1.5-2.0 \mathrm{mM}$ in the neonatal period (5-7, 26-28). From Fig. 5 and from an FFA/glycerol transport ratio of nearly 3 , one can estimate that neonatal glycerol flux is unlikely to surpass 7-8 $\mu \mathrm{mol} \mathrm{kg}{ }^{-1} \mathrm{~min}^{-1}$. Consequently, we should not expect glycerol to supply $>\sim 8 \%$ of neonatal hepatic glucose output (Fig. 4). Similarly, while tracer techniques underestimate actual gluconeogenic rates (52), the maximum contribution of glycerol to glucose production in our infants would have been $7 \%$ if all transported glycerol were converted to glucose (Table IV).

Nevertheless, a 5-8\% contribution to glucose production can be critically important to the newborn. A 3.5 - $\mathrm{kg}$ term newborn produces $\sim 20 \mathrm{mg}$ of glucose/ $\min (1)$, just about the glucose requirement of the 400 $\mathrm{g}$ newborn brain (1). This precarious fuel balance could be disturbed easily by a reduction in glycerol's contribution to glucose production if not matched by a simultaneous increase in delivery of other gluconeogenic substrate, by an exogenous source of glucose, or by the glucose-sparing effect of increased utilization of alternative fuels such as ketone bodies. Thus, as expected, accelerated lipid mobilization in the newborn serves a dual fuel balance role: delivery of substrate both for energy and for gluconeogenesis.

\section{ACKNOWLEDGMENTS}

We would like to thank the nurses of the Barnes Hospital Neonatal Unit without whose help these studies would have been impossible, Dale Osborne and Thomas Howard for their excellent technical assistance, and Dr. Richard Havel who suggested and surely would have completed this work $20 \mathrm{yr}$ ago had the appropriate nonradioactive tracers been available.
This work was supported by grants HD 10667, AM 20579, RR 00036, and RR 00954 from the National Institutes of Health. Dr. Bougnères was supported by fellowship grants from Fondation pour la Recherche Médicale and Ministère des Relations Extérieures, France.

\section{REFERENCES}

1. Bier, D. M., R. D. Leake, M. W. Haymond, K. J. Arnold, L. D. Gruenke, M. A. Sperling, and D. M. Kipnis. 1977. Measurement of "true" glucose production rates in infancy and childhood with 6,6 dideuteroglucose. Diabetes. 26: 1016-1023.

2. Sinclair, J. C. 1976. Metabolic rate and temperature control. In The physiology of the newborn infant. C. A. Smith and N. M. Nelson, editors. C. C. Thomas, Publisher, Springfield, IL. 354-415.

3. Sinclair, J. C. 1978. Temperature regulation and energy metabolism in the newborn. Grune and Stratton, Inc., New York. 187-204.

4. Van Duyne, and R. J. Havel. 1959. Plasma unesterified fatty acid concentration in fetal and neonatal life. Proc. Soc. Exp. Biol. Med. 102: 599-602.

5. Novak, M., V. Melichar, and P. Hahn. 1964. Postnatal changes in the blood serum content of glycerol and fatty acids in human infants. Biol. Neonate. 7: 179-184.

6. Chen, C. H., P. A. J. Adam, D. E. Laskowski, M. L. McCann, and R. Schwartz. 1965. The plasma free fatty acid composition and blood glucose of normal and diabetic pregnant women and their newborns. Pediatrics. 36: 843-855

7. Keele, D. K., and J. L. Kay. 1966. Plasma free fatty acid and blood sugar levels in newborn infants and their mothers. Pediatrics. 37: 597-604.

8. Benedict, F. G., and F. B. Talbot. 1915. Physiology of the newborn infant: character and amount of the katabolism. Carnegie Institute Publication No. 233. Carnegie Institute of Washington, Washington, DC.

9. Cross, K. W., J. P. M. Tizard, and D. A. H. Trythall. 1957. The gaseous metabolism of the newborn infant. Acta Paediatr. Scand. 46: 265-285.

10. Karlberg, P. 1952. Determination of standard energy metabolism in normal infants. Acta Paediatr. Scand. 41 (Suppl. 89): 151.

11. Widdowson, E. M., and C. M. Spray. 1951. Chemical development in utero. Arch. Dis. Child. 26: 205-214.

12. Fomon, S. J. 1967. Body composition of the male ref- 
erence infant during the first year of life. Pediatrics. 40: 863-870.

13. Widdowson, E. M. 1950. Chemical composition of newly born mammals. Nature (Lond.). 166: 626-628.

14. Novak, M., V. Melichar, P. Hahn, and O. Kodovsky. 1965. Release of free fatty acids from adipose tissue obtained from newborn infants. J. Lipid Res. 6: 91-95.

15. Galster, A. D., W. E. Clutter, P. E. Cryer, J. A. Collins, and D. M. Bier. 1981. Epinephrine plasma thresholds for lipolytic effects in man: measurement of fatty acid transport with $\left[1-{ }^{13} \mathrm{C}\right]$ palmitic acid. J. Clin. Invest. 67: 1729-1738.

16. Lowry, O. H., and J. B. Passonneau. 1972. A Hexible system of enzymatic analysis. Academic Press, Inc., New York. 175.

17. Bergmeyer, H. U. 1974. Methods of Enzymatic Analysis. Verlag Chemie, Weinhem, Germany. 4: 1825.

18. Bergmeyer, H. U. 1974. Methods of Enzymatic Analysis. Verlag Chemie, Weinhem, Germany. 4: 1836

19. Bougnères, P. F., and D. M. Bier. 1982. Stable isotope dilution method for measurement of palmitate content and labeled palmitate tracer enrichment in microliter plasma samples. J. Lipid Res. 23: 502-507.

20. Hagenfeldt, L. 1966. A gas chromatographic method for the determination of individual free fatty acids in plasma. Clin. Chim. Acta. 13: 266-268.

21. Bier, D. M., K. J. Arnold, W. R. Sherman, W. H. Holland, W. F. Holmes, and D. M. Kipnis. 1977. In vivo measurement of glucose and alanine metabolism with stable isotopic tracers. Diabetes. 26: 1005-1015.

22. Cassidy, G. 1966. Plasma volume studies in low birth weight infants. Pediatrics. 38: 1020-1027.

23. Hagenfeldt, L., J. Wahren, B. Pernow, and L. Raf. 1972. Uptake of individual free fatty acids by skeletal muscle and liver in man. J. Clin. Invest. 51: 2324-2330.

24. Chiasson, J. L., J. E. Liljenquist, W. W. Lacy, A. S. Jennings, and A. D. Cherrington. 1977. Gluconeogenesis: methodological approaches in vivo. Fed. Proc. 36: 229235.

25. Friedman, Z., A. Damon, E. L. Lamberth, and W. J. Mann. 1978. Cord blood fatty acid composition in infants and in their mothers during the third trimester. J. Pediatr. 92: 461-466.

26. Persson, B., and J. Gentz. 1966. The pattern of blood lipids, glycerol and ketone bodies during the neonatal period, infancy and childhood. Acta Paediatr. Scand. 55: $353-362$.

27. Heim, T. 1971. Thermogenesis in the newborn infant. Clin. Obstet. Gynecol. 14: 790-820.

28. Melichar, V., and H. Wolf. 1967. Postnatal changes in the blood serum content of glycerol and free fatty acids in premature infants. Biol. Neonate. 11: 50-60.

29. Hagenfeldt, L., and J. Wahren. 1975. Turn over of plasma free arachidonic and oleic acids in resting and exercising human subjects. Metabolism. 24: 799-806.

30. Hagenfeldt, L. 1975. Turnover of individual free fatty acids in man. Fed. Proc. 34: 2246-2249.

31. Hagenfeldt, L., A. Wennlund, P. Felig, and J. Wahren. 1981. Turnover and splanchnic metabolism of free fatty acids in hyperthyroid patients. J. Clin. Invest. 67: 16721677.

32. Bjorntörp, P., H. Bergman, E. Varnauskas, and B. Lindhelm. 1969. Lipid mobilization in relation to body composition in man. Metabolism. 18: 840-851.

33. Issekutz, B., Jr., W. M. Bortz, H. J. Miller, and P. Paul. 1967. Turnover rate of plasma FFA in humans and in dogs. Metabolism. 16: 1001-1009.

34. Eaton, R. P., M. Berman, and D. Steinberg. 1969. Kinetic studies of plasma free fatty acid and triglyceride metabolism in man. J. Clin. Invest. 48: 1560-1579.

35. Hall, S. E. H., J. Saunders, and P. H. Sonksen. 1979. Glucose and free fatty acid turnover in normal subjects and in diabetic patients before and after insulin treatment. Diabetologia. 16: 297-306.

36. Saunders. J., S. E. H. Hall, and P. H. Sonksen. 1980. Glucose and free fatty acid turnover in thyrotoxicosis and hypothyroidism before and after treatment. Clin. Endocrinol. 13: 33-44.

37. Fredrickson, D. S., and R. S. Gordon. 1960. The metabolism of albumin-bound $\mathrm{C}^{14}$-labeled unesterified fatty acids in normal human subjects. J. Clin. Invest. 39: 1504-1515.

38. Havel, R. J. 1972. Caloric homeostasis and disorders of fuel transport. N. Engl. J. Med. 287: 1186-1192.

39. Owen, O. E., and G. A. Reichard. 1971. Fuels consumed by man: the interplay between carbohydrates and fatty acids. Prog. Biochem. Pharmacol. 6: 177-213.

40. Havel, R. J., J. P. Kane, E. O. Balasse, N. Segal, and L. V. Bassa. 1970. Splanchnic metabolism of free fatty acids and production of triglycerides of very low density lipoproteins in normotri glyceridemic and hypertriglyceridemic humans. J. Clin. Invest. 49: 2017-2035.

41. Nestel, P. J., T. Ishikawa, and R. B. Goldrick. 1978 Diminished plasma free fatty acid clearance in obese subjects. Metabolism. 27: 589-597.

42. Bortz, W. M., P. Paul, A. C. Haff, and W. L. Holmes. 1972. Glycerol turnover and oxidation in man. J. Clin. Invest. 51: 1537-1546.

43. Lewis, B., W. Wittman, L. H. Krut, J. D. L. Hansen, and J. F. Brock. 1966. Free fatty acid flux through plasma in protein malnutrition of infants. Clin. Sci. 30: 371-375.

44. Krauss, A. N., and P. A. M. Auld. 1969. Metabolic requirements of low-birth weight infants. J. Pediatr. 75: 952-956.

45. Mestyan, J., and I. Rubecz. 1973. The metabolic patterns of premature infants receiving aminosol-glucose infusion. Acta Paediatr. Acad. Sci. Hung. 14: 319-328.

46. Rubecz, I., and J. Mestyan. 1973. Energy metabolism and intravenous nutrition of premature infants. $I$. The responses of oxygen consumption, respiratory quotient and substrate utilization to infusion of aminosol-glucose. Biol. Neonate. 23: 45-58.

47. Rubecz, I., J. Mestyan, P. Vangar, and L. Kluber. 1981 Energy metabolism, substrate utilization, and nitrogen balance in parenterally fed postoperative neonates and infants. J. Pediatr. 98: 42-46.

48. Hall, S. E. H., A. J. Hall, R. A. Layberry, M. Berman, and G. Hetenyi, Jr. 1976. Effects of age and fasting on gluconeogenesis from glycerol in dogs. Am. J. Physiol. 230: 363-367.

49. Okajima, F., M. Chenoweth, R. Rognstad, A. Dunn, and J. Katz. 1981. Metabolism of ${ }^{3} \mathrm{H}$ - and ${ }^{14} \mathrm{C}$-labeled lactate in starved rats. Biochem. J. 194: 525-540.

50. Frazer, T. E., I. E. Karl, L. S. Hillman, and D. M. Bier. 1981. Direct measurement of gluconeogenesis from [2,3${ }^{13} \mathrm{C}_{2}$ ] alanine in the human neonate. Am. J. Physiol. 240: E615-621.

51. Hall, S. E. H., R. Goebel, I. Barnes, G. Hetenyi, Jr., and M. Berman. 1977. The turnover and conversion to glucose of alanine in newborn and grown dogs. Fed. Proc. 36: 239-244.

52. Hetenyi, G., Jr. 1982. Correction for the metabolic exchange of ${ }^{14} \mathrm{C}$ for ${ }^{12} \mathrm{C}$ atoms in the pathway of gluconeogenesis in vivo. Fed. Proc. 41: 104-109. 